\title{
PREELIMINARY STUDY: WATER QUALITY PARAMETER ANALYZES OF SALT EVAPORATION PONDS IN KECAMATAN GALIS KABUPATEN PAMEKASAN, EAST JAVA
}

\author{
Onie Wiwid Jayanthi ${ }^{\mathrm{a} *}$, Ary Giri Dwi Kartika ${ }^{a}$, Widia Yuliati Ningsih ${ }^{\mathrm{a}}$, Zulia Susanti ${ }^{\mathrm{a}}$, \\ Ghetra Sanda Sascheva ${ }^{a}$ \\ ${ }^{a}$ Marine Science Departement, Faculty of Agricultural, University of Trunojoyo-Madura \\ Jl. Raya Telang PO BOX 2 Kamal-Bangkalan, East Java \\ *Corresponding author: onie.jayanti@trunojoyo.ac.id
}

\begin{abstract}
Water quality is an important parameter that affects the productivity and quality of salt produced in the traditional salt ponds. Environmental factors of water quality in salt ponds include bouzem plots, brine plots, peminihan ponds, and crystallization tables are important to be analyzed so that the quality of community salt can be improved, but some research is very limited about this so this research needs to be carried out. The method that used in this research is exploratory descriptive method by measuring water quality in bouzem plots, brine plots, evaporation ponds and crystallization tables. The result of water quality in bouzem plots (temperature $=32^{\circ} \mathrm{C} ; \mathrm{pH}=8,5 ; \mathrm{DO}=5,2 \mathrm{mg} / \mathrm{L}$; salinity $=2,5^{\circ} \mathrm{Be}$ ), evaporations ponds (temperature $=34^{\circ} \mathrm{C}$; $\mathrm{pH}=8,5-8,6 ; \mathrm{DO}=5,4-6,2 \mathrm{mg} / \mathrm{L}$; salinity $=34^{\circ} \mathrm{Be}$ ), brine plots (temperature $=39^{\circ} \mathrm{C} ; \mathrm{pH}=7,4-7,5 ; \mathrm{DO}=2,8$ $-3,3 \mathrm{mg} / \mathrm{L}$; salinity $=20^{\circ} \mathrm{Be}$ ), and crystallization tables (temperature $=38^{\circ} \mathrm{C} ; \mathrm{pH}=5,7-6,4 ; \mathrm{DO}=1,2-1,3$ $\mathrm{mg} / \mathrm{L}$; salinity $\left.=29^{\circ} \mathrm{Be}\right)$
\end{abstract}

Keywords: Water quality, Salt Evaporation Ponds, Pamekasan

\section{INTRODUCTION}

Indonesia has great marine resource potential, one of which is salt resource. National salt land area is around 27,898 hectares (Kementerian Kelautan dan Perikanan) ${ }^{[1]}$. One of the centers for salt production is Pamekasan, where salt production in 2014 reached $3.57 \%$ of the national salt production ${ }^{[2]}$.

Salt pond technology consists of multilevel crystallization technology and total crystallization technology. Water quality parameters in salt ponds that affect productivity and quality of salt include temperature, $\mathrm{pH}, \mathrm{DO}$, and salinity. Temperature will affect the rate of evaporation of sea water accelerate the rate of crystallization. The level of salt concentration in each salt pond plot determines the type of salt crystal compound formed ${ }^{[3]}$. Each salt plot on the farm must have an appropriate salt content value so that the $\mathrm{NaCl}$ compound to be produced.

This study aims to determine the parameters of water quality in salt ponds so that it will help the knowledge of ideal pond locations based on water quality parameters.

\section{MATERIAL AND METHOD}

This research was conducted on one salt pond with total crystallization technology in Galis, Pamekasan, East Java, which was carried out on August 7, 2019.

The method used in this study is exploratory descriptive method by measuring water quality in salt ponds with sampling points consisting of points on bouzem plots, evaporation ponds, brine plots and salt crystallization tables ${ }^{[4]}$.

Measurement of water quality parameters using in situ methods including parameters of temperature, $\mathrm{pH}, \mathrm{DO}$, and salinity by using a measurement tool according to the observed parameters. The measurement results are analyzed with the suitability of each parameter with the ideal salt pond plot.

\section{RESULT AND DISCUSSION}


Salt pond technology in Pamekasan uses a total crystallization method by utilizing the area of ponds for several plots including bouzem plots, evaporation ponds, brine plots and crystallization tables. The source of salt pond water is obtained from direct sea water which is accommodated in a pool of bouzem. After entering the pool of bouzem, sea water is put into an evaporation ponds to increase the salt content by evaporation proces in the pond. From the evaporation ponds then seawater is collected into an brine plots (according to the desired salt content) and then put into a crystallization table until it finally becomes salt. Salt evaporation pond construction that utilizes large land area with irregular plots which consist of ponds, if brine has been obtained is flowed to the crystallization table, is one form of salt evaporation ponds with complex table construction ${ }^{[5]}$. Each salt evaporation pond plot has different water quality parameter values.

Table 1. Salt Evaporation Ponds Water Quality Parameters

\begin{tabular}{lcccc}
\hline \multicolumn{1}{c}{ Located } & $\begin{array}{c}\text { Tempt } \\
\left({ }^{\circ} \mathrm{C}\right)\end{array}$ & $\begin{array}{c}\text { Salinity } \\
\left({ }^{\circ} \mathrm{Be}\right)\end{array}$ & $\begin{array}{c}\mathrm{DO} \\
(\mathrm{mg} / \mathrm{l})\end{array}$ & $\mathrm{pH}$ \\
\hline Bouzem Plots & 32 & 2,5 & 5,2 & 8,5 \\
\hline $\begin{array}{l}\text { Evaporation } \\
\text { Ponds }\end{array}$ & 34 & 4,3 & $5,4-6,2$ & $8,5-8,6$ \\
\hline Brine Plots & 39 & 20 & $2,8-3,3$ & $7,4-7,5$ \\
\hline $\begin{array}{l}\text { Crystallization } \\
\text { tables }\end{array}$ & 38 & 29 & $1,2-1,3$ & $5,7-6,4$ \\
\hline
\end{tabular}

The temperature in the bouzem plot is lower than the evaporation ponds, brine plots, and crystallization table which is $32^{\circ} \mathrm{C}$ this is because the bouzem plot has a higher depth than the pond pond, old water table, and crystallization table. Temperature affects the rate of evaporation of sea water so that the salinity can increase ${ }^{[6]}$.

Salinity level affect the results of the quality of the crystallization salts produced in salt evaporation ponds. If the concentration of salt is $3-6{ }^{\circ} \mathrm{Be}$, the salt crystals that settle are mud, sand, $\mathrm{Fe}_{2} \mathrm{O}_{3}$ or $\mathrm{CaCO}_{3}$, the salt content of $17-27{ }^{\circ} \mathrm{Be}$ which settles sulfate calcimate $(\mathrm{NaCl}), 27-35{ }^{\circ} \mathrm{Be}$ salt crystals that form Magnesium Salt, and the concentrations of salt $28-35{ }^{\circ} \mathrm{Be}$ which precipitate sulfate calcite $(\mathrm{NaCl}), 27-35{ }^{\circ} \mathrm{Be}$ salt crystals that form Magnesium Salt, and the concentration of salt $28-35{ }^{\circ} \mathrm{Be}$ which settles Sodium Bromide. In this salt evaporation ponds, brine plots are flowed to the crystallization table with a salt content of $20{ }^{\circ} \mathrm{Be}$ so that the quality of the salt produced more $\mathrm{NaCl}$ content obtained minimizes the presence of salt impurities ${ }^{[7]}$. In the salt evaporation ponds for each salt plot, the salinity has increased until the crystallization table shows that the evaporation rate of each plot has increased so that the salinity produced increases.

Dissolved oxygen (DO) levels decreased from bouzem plots, evaporation ponds, brine plots, and crystallization tables showed a change in salt concentration (increase in salt content) affecting dissolved oxygen in pond plots. The content of dissolved oxygen is useful for living organisms in salt evaporation ponds. Some organisms that can live on salt ponds are halophilic and halototerant organisms ${ }^{[8]}$. Some living organisms include fungi, microalgae Dunaliella salina, Artemia salina, several types of hallophilic bacteria that have the potential to increase the process of evaporation of sea water so that the crystallization process becomes faster ${ }^{[9]}$.

In the salt evaporation ponds plot shows the $\mathrm{pH}$ value of sea water will decrease the increasing value of the level of salt that has crystallized into salt ${ }^{[10]}$. The $\mathrm{pH}$ value of sea water with a salinity of $2,5^{\circ} \mathrm{Be}$ is 8,5 (alkaly) while the brine that will be channeled to the crystallization table with a salinity of $20{ }^{\circ} \mathrm{Be}$ has a $\mathrm{pH}$ of $7,4-7,5$ is a neutral $\mathrm{pH}$ (salt $\mathrm{pH})^{[11]}$.

\section{CONCLUSION}

Galis, Pamekasan salt evaporation ponds, with ponds including bouzem plots, evaporation ponds, brine plots and crystallization tables have water quality parameters, salinity, DO and $\mathrm{pH}$ ideal for the salt production process. Future studies are expected to not only analyze water quality samples in situ and also organic material, BOD, COD, TOM from salt evaporation ponds so that the water quality parameters analyzed are more complex.

\section{ACKNOWLEDGEMENT}

Acknowledgments were delivered to the LPPM University of Trunojoyo-Madura which has funded this research through the 
University of Trunojoyo-Madura independent grant 2019.

\section{REFERENCES}

[1] Salim, Z dan Ernawati, M. 2016. "Info Komoditi Garam". Jakarta. Badan Pengkajian dan Pengembangan Perdagangan Kementerian Perdagangan Republik Indonesia bekerja sama dengan Al Mawardi Prima Anggota IKAPI DKI Jaya.

[2] Data Produktivitas Lahan dan Kualitas Garam Periode 2011 -2014. Makalah: Disajikan Pada Rapat Teknis Harmonisasi Tarif Bea Masuk Garam Pada Tanggal 14 Desember 2015

[3] Rilley and Skirrow, 1975, Chemical Oceanography, 2nd edition, Academic Press London.

[4] Budi, M. S, dan Dhimas Wiharyanto. 2013. "Studi Kualitas Air Lingkungan Perairan Tambak Adopsi Better Management Practice (BMP) Pada Siklus Budidaya I, Kelurahan Karang Anyar Pantai Kota Tarakan Propinsi Kalimantan Utara.

[5] Santosa, I. 2014. Pembuatan Garam Menggunakan Kolam Kedap Air Berukuran Sama. Spektrum Industri, 2014, Vol. 12, No. 1, 1 - 112. ISSN : $1963-6590$

\section{COMMON ABBREVIATIONS}

Frequently used acceptable abbreviations are given below.

degree Celsius, ${ }^{\circ} \mathrm{C}$

degree Baume, ${ }^{\circ} \mathrm{Be}$

milligram, $\mathrm{mg}$

liter, 1
[6] Purbani, D., 2002, Proses Pembentukan Kristalisasi Garam dalam Rangka Kegiatan Sosialisasi Garam, Pusat Riset Wilayah Laut dan Sumberdaya Nonhayati, Badan Riset Kelautan dan Perikanan, Departemen Kelautan dan Perikanan.

[7] Nina G,C, Jose R, Ana P, 2009. Hallotolerant dan Halophilic Fungi. Mycological Reasearch 113 (2009) page 1231 - 1241. Journal Homepage: www.elseiver.com/locate/mycres

[8] Nilawati, Marihati, dan Rizal AM,. 2017. Kemampuan Isolat Bakteri Halocferax spp Dalam Meningkatkan Kemurnian Garam $\mathrm{NaCl}$ Pada Proses Kristalisasi. Jurnal Riset Teknologi Pencegahan Pencemaran Industri. Vol. 8 No. 2 (2017) 92-103

[9] Helena S, Muhammad Z, and Jusup S,. 2016. Microalgae Dunaliella salina (Teodoresco, 1905) Growth using the LED Light (Light Limiting Dioda) and Different Media. Aquatic Procedia 7 (2016) $226-230$.

[10] Tanji, et al. 1992. Salt deposits in evaporation ponds: an environmental hazard. California Agriculture, November - Desember 1992.

[11] Linda T. Green and Elizabeth M. Herron. 2003. Salt Ponds Monitoring Manual Supplement. University of Rhode Island Watershed Watch 